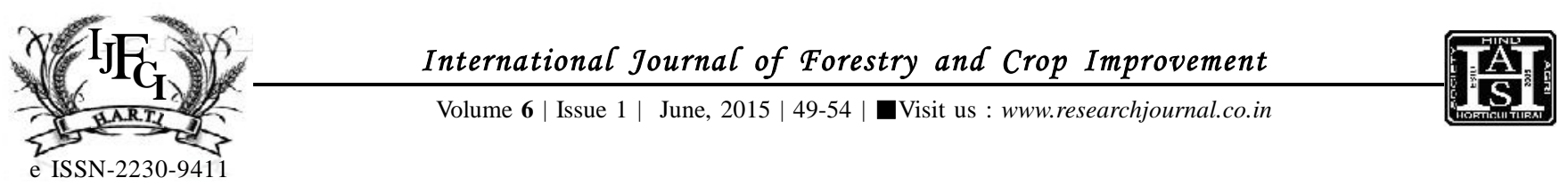

RESEARCH ARTICLE

DOI: $10.15740 / \mathrm{HAS} / \mathrm{IJFCI} / 6.1 / 49-54$

\title{
Evaluation of wheat sowing technologies under paddy residue conditions
}

\begin{abstract}
AJAIB SINGH
ABSTRACT : Evaluation of different wheat sowing technologies under paddy residue conditions were conducted in a combine harvested paddy field. Field of paddy variety PR-121 was harvested with combine. The straw load was $8.22 \mathrm{t} / \mathrm{ha}$ at moisture content of 20.2 per cent. Wheat variety (HD 2967) was sown with different farm machines viz., $\mathrm{T}_{1}:$ Happy seeder, $\mathrm{T}_{2}:$ Spatially modified no till drill and $\mathrm{T}_{3}$ : Roto till drill in combine harvested paddy fields. In $\mathrm{T}_{1}$, all the paddy straw was remained in the field itself but spreaded uniformly manually/stubble shaver, in $\mathrm{T}_{2}, 40$ per cent of loose paddy straw removed manually/chopping of paddy straw with paddy straw chopper cum spreader while in $\mathrm{T}_{3}$, there was a partial collection of loose paddy straw manually for better operation of the machines. The grain yield was maximum in treatment $T_{2}(5395.9 \mathrm{~kg} / \mathrm{ha})$.

KEY WORDS : Happy seeder, Spatially modified no till drill, Roto till drill, Paddy straw chopper cum spreader, Stubble shaver

HOW TO CITE THIS ARTICLE : Singh, Ajaib (2015). Evaluation of wheat sowing technologies under paddy residue conditions. Internat. J. Forestry \& Crop Improv, 6 (1) : 49-54.
\end{abstract}

ARTICLE ChroniCAL : Received : 16.03.2015; Revised : 24.04.2015; Accepted : 27.05.2015 